\section{$B D \cdot C E N T E R$}

Innovasyon ve Yayıneılık Merkezi

\section{Cypriot Journal of Educational Sciences}

Volume 16, Issue 5, (2021) 2248-2260

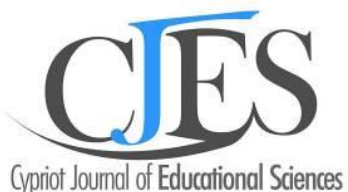

Cypriot Joumal of Educational Sciences

www.cjes.eu

\title{
Magnitude of Covid-19 on rural universities in the Eastern cape province: Lessons learnt
}

Marongwe Newlin $^{{ }^{*}}{ }^{*}$, Department of School Improvement Programmes, Walter Sisulu University, 56 Grey Street Queenstown Campus, South Africa.nmarongwe@wsu.ac.za

Chisango Grasiab, Department of Curriculum Studies, Walter Sisulu University, 56 Grey Street Queenstown Campus, South Africa. gchisango@wsu.ac.za

\section{Suggested Citation:}

Newlin, M. \& Grasia, C. (2021). Magnitude of Covid-19 on rural universities in the Eastern cape province: Lessons learnt. Cypriot Journal of Educational Sciences 16(5), 2248-2260. https://doi.org/10.18844/cjes.v16i5.6320

Received from; July 8,2021 revised from; August 11,2021, accepted from; October 22,2021. (C)2021 Birlesik Dunya Yenilik Arastirma ve Yayincilik Merkezi. All rights reserved.

\begin{abstract}
This research paper aims at assessing the impact of the Covid-19 pandemic on rural institutions of higher learning in South Africa. It further explores lessons learnt from the magnitude of the pandemic. Covid-19 does not discriminate - it spares no institution, no organisation, and no country but infects and affects everyone. Some institutions of learning, when hit by Covid-19 were better prepared to fight it because their alert levels were higher than that of African countries. This study adopted a desktop approach which relied on published data. The paper concludes that the impact of Covid-19 on institutions of higher learning was catastrophic. The magnitude of the Covid-19 pandemic on rural institutions of higher learning in South Africa was devastating because some universities had no strategy to counter the challenge. One of the lessons learnt was that the universities' think-tanks should plan in advance, be proactive, and be ahead of any challenge.
\end{abstract}

Keywords: Covid-19; e-learning; higher learning; impact; lessons; pandemic

* ADDRESS FOR CORRESPONDENCE: Marongwe Newlin, Department of School Improvement Programmes, Walter Sisulu University, 56 Grey Street Queenstown Campus, South Africa

E-mail address: nmarongwe@wsu.ac.za 
Newlin, M. \& Grasia, C. (2021). Magnitude of Covid-19 on rural universities in the Eastern cape province: Lessons learnt. Cypriot Journal of Educational Sciences 16(5), 2248-2260. https://doi.org/10.18844/cjes.v16i5.6320

\section{Introduction}

The successful curbing of pandemics of such gigantic proportions as Covid-19 depends on how effectively university management, lecturers and students are prepared in seriously utilising tools in managing, accessing, allocating, monitoring and evaluating the adoption and use of ICTs in learning and teaching. Higher Education Institutions [HEIs] should not only prepare students for the world of work, but also for flexibility and adaptability in dealing with crises of day-to-day life. The higher education sector should ensure that students are equipped with the necessary skills, the professional attributes and learning techniques that will help them to deal with outbreaks such as the Covid-19 pandemic. Students should be emotionally, psychologically, socially, financially and spiritually prepared for such an eventuality to be able to activate their innovative, flexible and level-headed capacities when faced with such problems. Predicting what may happen in future is difficult, since there are no references to similar cases. (UNESCO International Institute for Higher Education in Latin America and the Caribbean ,2020). In addition, Waruru (2020) states that the Covid-19 pandemic has suddenly come upon us and swamped us with innumerable uncertainties for the higher education sector, especially in terms of international relations and mobility.

Covid-19 is a new phenomenon not only in South Africa but also across the globe. Its impact has shaken every sector of life and its indiscriminate nature has affected all races, genders, and ages. Some institutions of learning were better prepared to combat Covid-19 because they were drawing lessons from previous natural disasters, and their alert levels were higher than that of South Africa and other sub-Saharan countries. For instance, in 2017, Mexico experienced a major earthquake that forced her to close all operations at some institutions of higher learning (Guerra-Achem, 2020). Mexico managed to get the students back on track in terms of teaching-learning in a week's time through online classes; and it significantly helped them to close the gap. What made it possible for Mexican students to bounce back was that the universities had developed ICT resources over the last 30 years in preparation for any crisis (Guerra-Achem, 2020).

The Covid-19 pandemic is a new catastrophic phenomenon that has wreaked havoc and left many people devastated and confused. Higher education sectors across the globe are not spared from this pandemic. Schools and universities face months of closure as a measure of flattening the curve of Covid-19. Fataar (2020) states that children and students from Black communities in South African schools, colleges and universities were asked to stay away from classes to prevent further spread of Covid-19 as packed spaces make social distancing difficult. Also, private companies, public organisations, and almost every sphere of society were affected by the Covid-19 crisis (Burquel \& Busch, 2020). According to the current literature, the snowballing effect of this pandemic has led to organisations, economies, health and school services collapsing, in addition to job losses and the unprecedented high rate of claiming for unemployment benefits (Burquel \& Busch, 2020). This situation will inevitably precipitate a global recession that would bring about untold misery, especially to the marginalised and poor. Xu (2020) states that more than half a million schools were closed indefinitely when the Covid-19 first broke out in China. To show how devastating the magnitude of the Covid-19 pandemic is, Besley (2020) advances that university international education was at a crossroads because it could not operate with closed borders or in an increasingly politicised environment of, among others, trade wars and immuno-wars. Besley (2020) further asserts that there could not be a return to "normal" for the neoliberal approach to international 
Newlin, M. \& Grasia, C. (2021). Magnitude of Covid-19 on rural universities in the Eastern cape province: Lessons learnt. Cypriot Journal of Educational Sciences 16(5), 2248-2260. https://doi.org/10.18844/cjes.v16i5.6320

higher education because its essential benefits were severely compromised by the global effects of the Covid-19 pandemic.

Literature holds that there was no doubt that globally we are living in perilous times exacerbated by the outbreak of the Covid-19 pandemic. University lecturers and students long for the university gates to be opened again but when reality dawned that we were in a total lockdown to protect every individual, they gradually began to grasp the implications and severity of the spread of such a devastating pandemic. Tesar (2020) laments that "university life had ceased to exist, the lights were turned off, the beating heart of the university had slowed down, and the virus had taken over" ( $p$. 39). In South Africa, the state of national disaster was declared by the Head of State (President Cyril Ramaphosa) on 16 March 2020, and the national lockdown was declared for over a month - this caused the closure of universities for an indefinite period. This lockdown impacted gravely on students especially those who could not access online teaching-learning applications due to reasons such as data unaffordability, poverty, no internet connectivity, lack of IT equipment (e.g. computer, laptop, tablet, smartphone, etc.) and lack of skills by some lecturers and students to work online, among other reasons. Fataar (2020) agrees that due to being historically disadvantaged, mainly Black students in South Africa were unable to purchase modern internet equipment for online learning. Mukeredzi et al. (2020) argue that the adoption of online teaching and learning during the national lockdowns, was rejected by a number of student organisations across Africa, contending that it was expensive, impractical and elitist. Mawaya claims that the proposals to run online classes was ignoring the fact that many students did not have access information and communication technology infrastructure, such as, internet connection (as cited in Mukeredzi et al., 2020). Although the Covid19 pandemic in terms of university activities such as online teaching-learning was engaging and intense, university management was insensitive to existing educational realities of an unequal society still reeling from the cascading effects of the brutalisation of apartheid. According to Fataar (2020), only $20 \%$ of the country's educational institutions had managed to move their curricula online, with varying levels of efficiency. Those few institutions which successfully forged ahead with online teaching were the ones that were previously advantaged having mainly students from white privileged families (Fataar, 2020).

The Covid-19 pandemic's calamitous effects traumatised most Black students who enrolled at rural universities. The digital divide between previously disadvantaged universities and privileged universities widened, and this was exposed by Covid-19. According to the researchers' observations, racial remarks and slurs were numerous and this re-opened the wounds as inequalities were openly exposed. According to Sehoole, cited in Waruru (2020), in South Africa, as elsewhere in Africa, the pandemic had exposed 'fault lines of inequalities', both in society and in higher education institutions. Many Black students could not access online learning and this caused untold anxiety to them. Fataar (2020) acknowledges that the majority of the country's (South Africa) students, Black and poor, were experiencing lockdown which hampered access to meaningful formal education. From Fataar's (2020) observations, it can be deduced that the Covid-19 pandemic's impact was hugely felt by students who were at educational institutions that could not leverage robust online platforms for learning. Additionally, Waruru (2020) mentions that there were also concerns that racial discrimination may grow in the wake of the disease, with learners from poorer countries (international students) being seen as "unsafe" as compared to those from wealthier countries. 
Newlin, M. \& Grasia, C. (2021). Magnitude of Covid-19 on rural universities in the Eastern cape province: Lessons learnt. Cypriot Journal of Educational Sciences 16(5), 2248-2260. https://doi.org/10.18844/cjes.v16i5.6320

Some universities in rural communities of South Africa experienced multiple confusion due to the outbreak of Covid19 pandemic, when they were caught unaware by the virus. A few fortunate Black universities in South Africa had some ICTs in place, but this paper argues that having technical knowhow is not enough as without appropriately training students and lecturers, especially in terms of accessing content knowledge, will not help curb the magnitude of the effects of Covid-19. According to Kalantzis and Cope (2020), the practices of education, especially, of schools and universities were suddenly disrupted because the danger was that, as teachers and students were forced to adopt online teaching and learning, they were further forced to use flawed systems with inadequate training, detrimental to quality e-learning experiences. Kalantzis and Cope (2020) argue that the rush to these online services might be less than desirable, since students already live in a digital world and are exposed to various technologies. However, universities had not provided the time for faculties to create digital learning spaces that avail such benefits. Kigotho (2020) reports that some eighty law students of Kenya's University of Nairobi went to court challenging the use of online learning platforms for classes and scheduled examinations in response to the Covid-19 pandemic restrictions. The students wanted the court to stop the university from holding virtual online classes due to a lack of prior consultation. Furthermore, one of the students, Kamau, cited inequalities exacerbated by online learning and argued that there had been glaring gaps in learning due to a lack of broadband internet access in rural areas where most students have been living since the university was closed on 15 March 2020. According to Kamau in Kigotho (2020), some students did not even have computers and had not been able to attend most of those online classes. Similar sentiments were shared by students in Ghana, Zimbabwe and other African countries (Mukeredzi et al., 2020).

The disastrous consequences of Covid-19 impacted heavily on university students' normal social and educational interactions. Tierney (2020) observes that students were quickly displaced; for instance, the peer culture and support that student were familiar with, and access to library and studio venues.

Some researchers admit that Covid-19 has caused divisions among people and eroded the concept of ubuntu (humanity) - even in institutions of higher learning. Most governments were caught up in a dilemma of wanting to balance life and the economy. Citizens were asked to take responsibility for their own lives. "As the coronavirus pathogen spreads roughshod across the world, it affects our 'right to breathe', causing us finally to account for our own death" (Mbembe, 2020, as cited in Fatart, 2020, p. 27). Sharing the same sentiment, Misiaszek (2020) states that the lack of ethics and morality of neoliberalism has emerged from the pandemic, as questions of "opening up economies" were prioritised over human life and local-to-global collectivism. The regular to-and-fro of students to get back to schools and universities escalated Covid-19 cases and fatalities. For instance, there were 5 647 Covid-19 positive cases in South Africa on the 30th of April and the number skyrocketed to 553188 on the 8th of August 2020 (RSA, Department of Health, 2020). This highlights that people including students got infected rapidly by Covid-19 - a great cause of distress (Mukeredzi et al., 2020).

Different types of specialist health workers inter alia social workers, psychologists, virologists, and nurses were always on their toes trying to offer medical assistance to victims (both infected and affected). It was reported in the media that some South African university students decided to deregister for 2020; some because of economic hardships, trauma and not having hope for 
Newlin, M. \& Grasia, C. (2021). Magnitude of Covid-19 on rural universities in the Eastern cape province: Lessons learnt. Cypriot Journal of Educational Sciences 16(5), 2248-2260. https://doi.org/10.18844/cjes.v16i5.6320

tomorrow (Mukeredzi et al., 2020). This had a negative economic effect on universities that lost revenue because of students' deregistering. Fears of the uncertainty of tomorrow by universities and students created a panic situation. Waruru (2020) observed that this also was prevalent in universities beyond the borders of South Africa, and noted that all universities were faced with massive losses in revenues even after shifting learning to online platforms, in addition to queries about whether all students will return from their home countries after the pandemic. Waruru (2020) adds that it was also unclear whether universities could continue charging normal fees for programmes that had shifted to online portals, especially for those who had paid for face-to-face learning and will international students expect refunds of their fees for the time they were away.

This shows the intensity of the devastation caused by Covid-19 because universities are now facing the dilemma of becoming financially depleted and did not know how staff salaries and other running expenses would be paid. Conroy (2020) states that the economic disadvantages of the lockdown will have far-reaching dire effects on university education. Jandric (2020) suggests that:

The Covid19 pandemic was an interesting case of individual-versus-collective responsibility in its own right - it provides people with a once-in-a-lifetime opportunity to re-examine the fragile, ever-changing balance between our individual and collective interests. This brings in the idea of lack of morality impelled by Covid19. (p. 35).

Based on the literature reviewed, there exists a research gap, especially, in respect of the impact of the Covid-19 pandemic on rural institutions of higher learning, particularly in the Eastern Cape Province of South Africa. There is little or no research that has been carried out to assess the impact of Covid-19 in this geographical location. Most literature focused on new learning possibilities and innovative interventions of education processes in emergency situations. This paper intends to draw lessons that can be learnt by HEls from the havoc that has been caused by the Covid-19 in preparation for other unprecedented crises that may arise in the future. Given this research gap (identified above), there is a justification for this kind of research investigative paper that provides lessons that can be learnt to combat similar Covid-19 problems.

\section{Methods and Materials}

Desktop research is defined as "the process of accessing published secondary data" (Jackson, 1994, as cited in Al-Awamleh \& Alkhalaileh, 2020, p. 21). Researchers for this study relied on published data, and as such, research findings were obtained through online desktop-based research. Through this research, we drew on examples from various countries to explore the magnitude of Covid-19 on rural institutions of learning. The reviewed data were obtained from available online information and statistics. Data were obtained from local sources, such as government documents and newspapers, regional data, as well as global information and statistics. Statistical data were mainly derived from South African general household surveys conducted in 2016 and 2018. The statistical data obtained from the household surveys was used to dissect issues of the availability of ICT infrastructure in South African homes in rural and urban areas. The World Bank and the International Telecommunication Union [ITU] were also sources of statistical data, especially data related to internet connectivity and electricity supply in the sub-Saharan African region. Universities in South Africa were a key source of information on the adoption of online teaching and learning by local universities. Statistics obtained 
Newlin, M. \& Grasia, C. (2021). Magnitude of Covid-19 on rural universities in the Eastern cape province: Lessons learnt. Cypriot Journal of Educational Sciences 16(5), 2248-2260. https://doi.org/10.18844/cjes.v16i5.6320

from Mawazo's (2020) survey in Africa provided important and relevant data on the impact of Covid19 on Africa's higher education system. They also provided a broader perspective covering East, West and Southern Africa, allowing comparisons to be made. A combination of all these sources provided information on the magnitude the Covid-19 pandemic had on rural institutions of higher learning.

\section{Discussion}

The spread of Covid-19 across the globe has impacted all sectors of the economy, and institutions of learning have not been spared. The most immediate impact for students was felt in the temporary cessation of face-to-face teaching and learning at HEls. Students were left in a dilemma, not knowing how long it would last (UNESCO International Institute for Higher Education in Latin America and the Caribbean [IESALC], 2020). Mahaye (2020) is of the view that the temporary closure of institutions of learning results in curriculum disruption which might take long to recover from, and that some students might not return even when the crisis has ended.

The closure of universities has resulted into "an abrupt entry into a new era of learning" (IESALC, 2020, p. 21). A swift digital transformation of universities requires the adoption and use of information and communication technology (ICT) and digitally competent teachers and students, among other things. With little or no time at all to prepare for such an abrupt entry into e-learning, some teachers have been faced with challenges concerning ICT skills and the ability to adapt to this new teaching method, including designing the course materials and content for online systems.

Covid-19 has also exposed the digital divide in some regions, especially, in sub-Saharan Africa. For instance, about $90 \%$ of students in sub-Saharan Africa do not have access to household computers and $82 \%$ are unable to get connected to the internet (United Nations: Policy Brief: Impact of Covid-19 in Africa, 2020). The closure of schools has therefore, left over 330 million learners and over 8.5 million teachers, who are unable to access learning or teaching from home. Mobile phones can be used to support students, but approximately 56 million students live in areas that have limited or no connection to mobile networks. Furthermore, there were approximately $87 \%$ of households in South Africa that owned a mobile phone but connectivity was a problem in rural areas (South Africa: General Household Survey, 2018). Another challenge faced by the sub-Saharan student is that there is unreliable power supply (World Bank 2008; United Nations: Policy Brief: Impact of COVID-19 in Africa, 2020). Research conducted revealed that approximately 609 million people in Sub-Saharan Africa did not have access to electricity supply, and about 530 million people will not have access by 2040 due to population growth (The World Bank, 2017).

To further explore the digital divide in some regions, the ITU (2020) states that below 20\% of households and below $50 \%$ of households in Africa and Latin America and Caribbean respectively, had internet connection in 2018. Such low internet connection statistics at homes is a clear indication that most students in Africa are left out of the e-learning process. This is so despite one of UNESCO's (2020) principles of finding innovative ways out of the crisis - we must adhere to the slogan of "Leave no student behind". (p. 7). Research conducted by the Mawazo Institute (2020) in East, West and Southern African regions, revealed that $82.6 \%$ of respondents reported that their classes were affected by Covid-19. Only $38.5 \%$ were at institutions offering e-learning, and this low percentage does not only indicate a critical gap for learning for students in the region, but the existence of the 
Newlin, M. \& Grasia, C. (2021). Magnitude of Covid-19 on rural universities in the Eastern cape province: Lessons learnt. Cypriot Journal of Educational Sciences 16(5), 2248-2260. https://doi.org/10.18844/cjes.v16i5.6320

digital divide which is perpetuated by socio-economic factors. Though some institutions in the region offer e-learning, Mawazo Institute (2020) found that there were disparities in accessing e-learning. For instance, only $17.2 \%$ of West African respondents reported being at institutions with e-learning options, compared to $43.1 \%$ of East African respondents, and $40.5 \%$ of Southern African respondents.

Some students, especially those from abroad, are unable to return to their own countries due to the closure of airports and borders (Republic of South Africa (RSA): Department of International Relations and Cooperation, 2020). Alabi acknowledges that questions had arisen since the outbreak of Covid-19 including whether expired visas will be extended, and whether students will have to pay for these extensions (as cited in Waruru, 2020). Sehoole, cited in Waruru (2020), perceives that the Covid-19 pandemic was also likely to hit students financially in terms of travelling expenses directly or indirectly, thereby negatively affecting the throughput rate. According to Sehoole, a reduction in available funds for scholarships, may seriously affect rural Black students from accessing tertiary education.

Additionally, IESALC (2020) reports that some university students will be affected socially and emotionally since their socialisation-routines were abruptly brought to a halt. For instance, a survey carried out in the USA among higher education students revealed that $75 \%$ experienced anxiety and depression as a result of Covid-19 (IESALC, 2020). A survey carried out in the African region revealed similar findings that Covid-19 "has led to uncertainty and anxiety about the future" (Mawazo Institute, 2020, p. 8). Some HEls have however, initiated psychological and socio-emotional support mechanisms for students; for instance, the Franz Tamayo University in Bolivia has 13 psychologists available to support the university community, in situations of isolation.

Furthermore, findings by Watts (2016) reveal that undergraduates are less prepared to change the mode of teaching and learning. The change to online platforms was not received positively by some students; for example, students from the University of Johannesburg (UJ) via the interim SRC were on social media calling for the institution to suspend online classes (Call to Suspend Online Learning at UJ, 2020). Reasons were described as characteristics related to technological, contextual and individualistic aspects (Sesabo et al., 2015). Individual characteristics, such as a lack of ICT training of teachers and students hinders the adoption of e-learning as a teaching and learning tool (Chisango, 2020). A technological challenge faced by, for instance, South African students, is limited internet access at home. A 2016 household survey in the country revealed that home internet is mainly accessed by households in the Western Cape (23.6\%) and Gauteng (14.8\%), compared to rural households in Limpopo (1.6\%) and Eastern Cape (3.9\%) (South Africa: General Household Survey, 2016). This is due to poor infrastructure, especially in rural areas, and high costs of the internet services (Chisango \& Lesame, 2017). It can be argued that students who are from predominantly rural universities and homes are on the "wrong side" of the digital divide and might not be able to meaningfully participate in online platforms.

It is also argued that the content offered was not designed for distance education, but "rather tries to make up for the absence of face-to-face classes with virtual classes without further preparation" (IESALC, 2020, p. 19). It is worthwhile to note that Blade Nzimande, the Minister of Higher Education and Training in South Africa, advised the return of final year students in programmes that require clinical training such as medicine $(\mathrm{MBChB})$, nursing, dentistry, and veterinary sciences under 
Newlin, M. \& Grasia, C. (2021). Magnitude of Covid-19 on rural universities in the Eastern cape province: Lessons learnt. Cypriot Journal of Educational Sciences 16(5), 2248-2260. https://doi.org/10.18844/cjes.v16i5.6320

lockdown level 4, which started on the $1^{\text {st }}$ of May 2020 (RSA: Department of Higher Education and Training, 2020). The Minister explained that under lockdown level 3, a maximum of $33 \%$ of the student population is allowed to return to campuses and residences provided that the institution can safely support them in terms of health and safety protocols as directed by the Department of Health and DHET.

Some universities in South Africa such as the University of Witwatersrand (WITS) and the University of Cape Town (UCT) were ready to roll-out online learning from 20 April 2020. For instance, WITS purchased and distributed data to most of its students - only about $10 \%$ of students did not have access to ICT infrastructure, but the university already planned contact teaching sessions with such students (Universities South Africa [USAF], 2020). The scenario at predominantly rural and disadvantaged universities, such as Walter Sisulu University (WSU) and the University of Fort Hare (UFH), was different (USAF, 2020). At WSU, $90 \%$ of students did not have access to ICT infrastructure and online learning was impossible at that particular moment in time. Also, UFH was faced with the same predicament with $70 \%$ of the students not having access to ICT, which was compounded by poor connectivity (USAF, 2020). The contrasting scenarios at metropolitan universities and rural universities clearly exposes the existing digital divide among students in South Africa. Sehoole observes that in South Africa some universities, especially those well-endowed financially, were more able to transition to online learning thanks to their superior infrastructure (as cited in Waruru, 2020). They were also able to support poor students in accessing the internet and other learning devices.

Research is also another crucial component at university which was affected by the pandemic. Respondents in East Africa revealed that $70.3 \%$ of laboratory and field research was suspended in East Africa, $79.8 \%$ in West Africa and 69\% in Southern Africa (Mawazo Institute, 2020). Course interruptions were also experienced at universities in the African region, with more females affected than males. For instance, In East Africa, 83.8\% females experienced course interruptions compared to their male counterparts (80\%). In Southern Africa, $87 \%$ of females compared to $78.9 \%$ males were affected by course interruptions (Mawazo Institute, 2020). More females might have experienced more course interruptions than males because of differences in ICT access as revealed by the ITU (2016). Statistics revealed by ITU (2016) indicate that in Africa only $21.9 \%$ of women have access to the internet, compared to $28.4 \%$ males. Moreover, it is postulated that women often do not have adequate financial resources and thus lack equal opportunities to access ICTs (The South African Institute of International Affairs [SAIIA], 2017).

\section{Lessons learnt}

The outbreak of the Covid-19 pandemic across the globe was a wake-up call to most governments and institutions of higher learning. It can be learnt that pandemics of such nature need to be prepared for well, in advance before they manifest. Some universities in South Africa and across Africa dragged their feet to adopt technology as a system in teaching and learning. The reluctance in the adoption of ICTs could have been attributed to not having procured adequate ICT gadgets and proper ICT infrastructure. The Covid-19 pandemic has now made university management authorities to open their eyes and put in place online process before the outbreak of another natural disaster. According to different reports, memos, circulars and other communiques that were sent to university staff and students, it was evident that some universities had no clear-cut policies to handle such 
Newlin, M. \& Grasia, C. (2021). Magnitude of Covid-19 on rural universities in the Eastern cape province: Lessons learnt. Cypriot Journal of Educational Sciences 16(5), 2248-2260. https://doi.org/10.18844/cjes.v16i5.6320

crises. These universities rushed to sit down and craft emergency policies in a knee-jerk reaction to address the dire situation in order to rescue the academic calendar. Since HEIs are regarded as thinktanks to solve society's problems, they should plan in advance and always be at the cutting-edge of innovations to challenge disasters. Obanya states that the pandemic had exposed the need to transform teaching from a face-to-face to "mind-to-mind" engagement in order for institutions to survive future upheavals (as cited in Waruru, 2020). Universities also need to offer e-learning skills as an integral part of ongoing training for academics.

Additionally, students and academics should be trained to use newer approaches to teaching and learning and should be prepared to go the extra mile and come out of their comfort zones. Natural pandemics come unannounced and governments and universities must always have a "Plan B" in place. There are scientists, meteorologists and some researchers who are always researching and communicating their findings and recommendations. These studies should be taken seriously and instituted when needed as per the recommendations. Furthermore, governments that are not normally hit by natural disasters should learn from governments that are always affected and try to implement some of the strategies in order to curb and reduce the impact of pandemics such as Covid19.

The experiences from Covid-19 should be interrogated to find solutions for future planning for other unknown disasters that might invade us in the future. From literature, the Covid-19 exposed inequalities in South Africa socially, economically, health-wise, and educationally. The implication is that the curricula should be transformed to address the problem of inequality in South Africa. The digital divide has widened and deepened and this has to be redressed urgently. Rural universities are struggling to ensure the smooth running of online or remote classes. Similarly, according to Misiaszek (2020), governments should therefore utilise the diverse experiences from Covid-19 to eradicate discriminatory education by avoiding shallow content knowledge, by encouraging critical discourse analysis, critical- thinking, problem-solving, innovativeness, and reading that frowns upon using violence as a means to change people's false perceptions (Misiaszek, 2020).

Universities, mentioned above, should have clear staff recruitment policies and staff development policies ensuring that as institutions of higher learning only the best intellectuals should be recruited. This applies right from recruiting university management leadership who should be versatile, visionary, dynamic, creative, deep-thinkers, problem- solvers, flexible, and not individuals who pander to the whims and fancies of university councils. This policy should cascade to the recruitment of academics including non-academics. Qualifications, abilities, capabilities, potential, experience and change-management should not be downplayed, but utilised to better society. Academic returnees should be lured to join universities in their home countries. Waruru (2020) posits that Africa could also gain by engaging academics who have returned home in the wake of the pandemic, and who may not return to their previous stations abroad. Waruru (2020) further observes that retaining them at home would be an opportunity to reverse the brain drain. It is recommended that universities should equip lecturers with the necessary skills and also provide them with both hardware and software for them to effectively teach and research online and prepare for future challenges (Obanya, 2020, as cited in Waruru, 2020). 
Newlin, M. \& Grasia, C. (2021). Magnitude of Covid-19 on rural universities in the Eastern cape province: Lessons learnt. Cypriot Journal of Educational Sciences 16(5), 2248-2260. https://doi.org/10.18844/cjes.v16i5.6320

Furthermore, the University of Botswana's Vice-chancellor, Professor David Norris stated that African countries should be self-reliant when it comes to dealing with societal challenges, and that there should be greater collaboration with African partners (Dell, 2020). Thus departments, governments and industries should collaborate in finding solutions to problems, such as pandemics. Nations across the globe have been working "inwardly" to ease the effects of Covid-19. A further revelation is that Western countries are thinking of ways to help themselves - few might be thinking of helping Africa. Hence, African nations should rely upon themselves for survival. Sehoole posits that institutions of higher learning must collaborate in the fields of, for instance, infectious diseases and epidemiology (as cited in Waruru, 2020).

\section{Conclusion}

Based on the online desktop research findings, this study recommends that institutions of higher learning should provide tools of trade, such as data, laptops and tablets, to lecturers and students, so that they are able to meaningfully engage in online teaching and learning processes. The greatest challenge faced by universities, especially the rural disadvantaged ones, is that internet connection is expensive, and internet connectivity is very limited. The lockdown of institutions of learning to curb the spread of Covid-19 can be said to be a threat to the future of students, especially, from previously disadvantaged universities which were not prepared for online teaching and learning. Universities should therefore invest to ensure that students and lecturers have access to the internet and other ICT facilities such as laptops, which support the installation of learning management system applications, for instance, Blackboard and Moodle. Lecturers should be continuously capacitated with ICT skills so that they also assist students effectively. Providing ICT infrastructure to students might close the digital divide between students at "underprivileged" and "privileged" universities. The study therefore, concludes that the disastrous effects of Covid-19 on rural institutions of higher learning in the Eastern Cape Province were enormous and universities need to draw lessons from this pandemic in preparation for other similar or unknown crises including natural disasters.

\section{References}

Al-Awamleh, R. A., \& Alkhalaileh, Y. S. (2020). The American-Turkish Relationship and its Effect on the Syrian Crisis. Mediterranean Journal of Social Sciences, 10 (6), 1-9.

\section{https://www.richtmann.org/journal/index.php/mjss/article/view/10588}

Besley, T. (2020). The crisis of neoliberal university international education. In M.A. Peters (Ed.), Reimagining the new pedagogical possibilities for universities post-Covid-19: Educational Philosophy and Theory. (pp. 40-41). Routledge, Taylor \& Francis Group.

\section{https://doi.org/10.1080/00131857.2020.1777655}

Burquel, N., \& Busch, A. (2020, April 25). Lessons for international higher education post COVID-19. University World News: The Global Window on Higher Education.

https://www.universityworldnews.com/post.php?story=2020042408501836

Call to suspend online learning at UJ. (2020, July 13).

http://www.enca.com/news/uj-hold-online-classes-amid-outcry-src 
Newlin, M. \& Grasia, C. (2021). Magnitude of Covid-19 on rural universities in the Eastern cape province: Lessons learnt. Cypriot Journal of Educational Sciences 16(5), 2248-2260. https://doi.org/10.18844/cjes.v16i5.6320

Chisango, G. (2020). The adoption and use of information and communication technologies (ICTs) in teaching and learning at township secondary schools in Sedibeng West District Municipality [Doctoral dissertation: University of South Africa].

http://uir.unisa.ac.za/bitstream/handle/10500/26294/thesis_chisango_g.pdf?sequence=1\&isAllowed=y

Chisango, G., \& Lesame, C. (2017). Challenges of information and communication technology policy implementation in rural South Africa. Communitas, 22, 48-61.

https://doi.org/10.18820/24150525/Comm.v22.4

Conroy, J. (2020). Higher education after the virus. In M.A. Peters (Ed.), Reimagining the new pedagogical possibilities for universities post-Covid-19: Educational Philosophy and Theory (pp. 16-17). Routledge, Taylor \& Francis Group.

\section{https://doi.org/10.1080/00131857.2020.1777655}

Dell, S. (2020, August 24). COVID-19 highlights need for self-reliance in Africa.

https://www.universityworldnews.com/post.php?story=20200509111034880.

Fataar, A. (2020). Educational transmogrification and exigent pedagogical imaginaries in pandemic times. In M.A. Peters \& F. Rizvi (Eds.), Reimagining the new pedagogical possibilities for universities post-Covid-19. Educational Philosophy and Theory (pp. 27-28). Routledge, Taylor \& Francis Group. https://doi.org/10.1080/00131857.2020.1777655

Guerra-Achem, J. (2020, April 25). Lessons from the earthquake on handling the pandemic. Global. University World News.

https://www.universityworldnews.com/post.php?story=2020042215543292

International Telecommunication Union. (2016). Information and communication technology statistics. www.itu.int/en/ITU-D/Statistics/Pages/stat/default.aspx

Jandric, P. (2020). What kind of university do we deserve? In M. A. Peters \& F. Rizvi (Eds.), Reimagining the new pedagogical possibilities for universities post-Covid-19: Educational Philosophy and Theory (pp. 22-27). Routledge, Taylor \& Francis Group.

\section{https://doi.org/10.1080/00131857.2020.1777655}

Kalantzis, M., \& Cope, B. (2020). After the COVID-19 crisis: Why higher education may (and perhaps should) never be the same. In M. A. Peters \& F. Rizvi (Eds.), Reimagining the new pedagogical possibilities for universities post-Covid-19: Educational Philosophy and Theory (pp. 24-27). Routledge, Taylor \& Francis Group.

https://doi.org/10.1080/00131857.2020.1777655

Kigotho, W. (2020, July 01). Law students approach courts to challenge online exams. Africa-Global, University World News.

https://www.universityworldnews.com/post.php?story=2020070108564996

Mahaye, N. E. (2020). The Impact of COVID-19 Pandemic on Education: Navigating Forward the Pedagogy of Blended Learning. Department of Education: KwaZulu-Natal, South Africa. https://www.academia.edu/42842598/The_Impact_of_COVID_19_Pandemic_on_Education_Navigating_Forwa rd_the_Pedagogy_of_Blended_Learning.

Mawazo Institute. (2020). Survey Report: The impact of covid-19 on Africa's higher education system. http://www.mawazoinstitute.org/our-publications. 
Newlin, M. \& Grasia, C. (2021). Magnitude of Covid-19 on rural universities in the Eastern cape province: Lessons learnt. Cypriot Journal of Educational Sciences 16(5), 2248-2260. https://doi.org/10.18844/cjes.v16i5.6320

Misiaszek, G. (2020). COVID-19 foreshadowing Earth's environmental tipping point: Education's transformation needed to avoid the ledge. In M. A. Peters \& F. Rizvi (Eds.), Reimagining the new pedagogical possibilities for universities post-Covid-19: Educational Philosophy and Theory. (pp. 38-39). Routledge, Taylor \& Francis Group. https://doi.org/10.1080/00131857.2020.1777655

Mukeredzi, T., Kokutse, F., \& Dell, S. (2020, April 02). Student bodies say e-learning is unaffordable and elitist. University World News: The Global Window on Higher Education. NewzRoom Africa Channel 405.

https://www.universityworldnews.com/post.php?story=20200422075107312

Republic of South Africa: Department of Higher Education and Training. (2020). Minister Blade Nzimande: Implementation of measures by the post school education sector in response to Coronavirus Covid-19 pandemic. https://www.gov.za/speeches/minister-blade-nzimande-implementation-measures-post-school-educationsector-response

Republic of South Africa: Department of Health. (2020). Update on Covid-19 (30th April 2020).

www. sacoronavirus.co.za/2020/04/30/update-on-covid-19-30th-april-2020/

Republic of South Africa: Department of Health. (2020). Update on Covid-19 (08th August 2020). Retrieved from www.sacoronavirus.co.za/2020/08/08/update-on-covid-19-08th-august-2020/

Republic of South Africa: Department of International Relations and Cooperation. (2020). Speaking Notes by the Minister of International Relations and Cooperation, Dr Naledi Pandor, on Repatriations of South Africans stranded abroad, (21 May 2020).

http://www.dirco.gov.za/docs/speeches/2020/pand0521.htm

South Africa: General Household Survey. (2018). Statistical Release P0318: General household survey. www.statssa.gov.za/publications/P0318/P03182018.pdf

Sesabo, J. K, Mfaume, R. \& Msabila, D. T. (2015). Opportunities and challenges in implementing distance learning and e-learning: A case study. In J. Keengwe, (Ed.), Handbook of Research on Educational Technology Integration and Active Learning. (pp. 329-345). Hershey, PA: IGI Global. Doi: 10.4018/978-14666-8363-1.ch016.

South Africa: Genera Household Survey. (2016). Statistical Release P0318: General household survey. www.statssa.gov.za/publications/P0318/P03182016.pdf

Tesar, M. (2020). Post-Covid-19: Questioning the new pedagogical possibilities (review). In M. A. Peters \& F. Rizvi (Eds.), Reimagining the new pedagogical possibilities for universities post-Covid-19: Educational Philosophy and Theory. (pp. 39-40). Routledge, Taylor \& Francis Group.

\section{https://doi.org/10.1080/00131857.2020.1777655}

The South African Institute of International Affairs (SAlIA). (2017). No woman left behind: The gender digital divide. www.saiia.org.za/research/no-woman-left-behind-the-gender-digital-divide/

The World Bank. (2008). Sustainable Infrastructure Action Plan-FY 2009-2011: The World Bank Group. Washington: World Bank.

http://documents1.worldbank.org/curated/en/442391468316130724/pdf/436920coverOSIAP1Final1front1back .pdf

The World Bank. (2017). State of Electricity Access Report (SEAR). Washington: World Bank.

http://hdl.handle.net/10986/26646

Tierney, R. J. (2020). Universities on their back foot - the Covid 19 interruption (review). In M. A. Peters \& F. Rizvi (Eds.), Reimagining the new pedagogical possibilities for universities post-Covid-19: Educational Philosophy and Theory. (pp. 37-38). Routledge, Taylor \& Francis Group. 
Newlin, M. \& Grasia, C. (2021). Magnitude of Covid-19 on rural universities in the Eastern cape province: Lessons learnt. Cypriot Journal of Educational Sciences 16(5), 2248-2260. https://doi.org/10.18844/cjes.v16i5.6320

\section{https://doi.org/10.1080/00131857.2020.1777655}

UNESCO International Institute for Higher Education in Latin America and the Caribbean. (2020). COVID-19 and higher education: Today and tomorrow: Impact analysis, policy responses and recommendations.

http://www.guninetwork.org/publication/report-covid-19-and-higher-education-today-and-tomorrow-impactanalysis-policy-responses.

United Nations. (2020). Policy Brief: Impact of Covid19 in Africa. https://unsdg.un.org/sites/default/files/202005/Policy-brief-Impact-of-COVID-19-in-Africa.pdf.

Universities South Africa. (2020). Emergency Teaching and Learning during the COVID-19 Era. www.usaf.ac.za/universities-coronavirus-covid-19-updates/

Waruru, M. (2020, July 16). Internationalisation and COVID-19 - Challenges and lessons. Africa-Global. University World News.

https://www.universityworldnews.com/post.php?story=20200715110850412

Watts, L. (2016). Synchronous and asynchronous communication in distance learning: A review of the literature. Quarterly Review of Distance Education, 17(1), 23-32.

https://search.proquest.com/scholarly-journals/synchronous-asynchronous-communicationdistance/docview/1794526758/se-2?accountid=36534

$\mathrm{Xu}, \mathrm{Q}$. (2020, April 25). Planning for lockdown and how to emerge out of it. China - Global. University World News.

https://www.universityworldnews.com/post.php?story=20200422155817600 